\title{
Evidence Use and the Institutions of the State: The Role of Parliament and the Judiciary
}

Stefanie Ettelt

\section{INTRODUCTION}

Most analyses of the role of scientific evidence in health policy see health system governance as predominantly the responsibility of the Government, with the Ministry of Health being its main representative. The World Health Organization (WHO), for example, emphasised the steering role of ministries in improving health and health system performance (Travis et al. 2002). Yet what is sometimes overlooked is that ministries operate in context, with other state institutions interacting and shaping its role. The Ministry of Health may be the main actor responsible for health within the executive, but it operates within a larger institutional context, i.e. the 'political system'. This definition by Scott and Mcloughlin emphasises the interaction of formal and informal institutions that shape the plethora of political processes, roles and responsibilities that together form the state:

\footnotetext{
S. Ettelt $(\bowtie)$

London School of Hygiene and Tropical Medicine, London, UK e-mail: stefanie.ettelt@lshtm.ac.uk

(C) The Author(s) 2018

J. Parkhurst et al. (eds.), Evidence Use in Health Policy Making, International Series on Public Policy, https://doi.org/10.1007/978-3-319-93467-9_9
}

185 
Political systems are the formal and informal political processes by which decisions are made concerning the use, production and distribution of resources in any given society. Formal political institutions can determine the process for electing leaders; the roles and responsibilities of the executive and legislature; the organisation of political representation (through political parties); and the accountability and oversight of the state. Informal and customary political systems, norms and rules can operate within or alongside these formal political institutions. (Scott and Mcloughlin 2014: n.p.)

This chapter examines the role of two of the institutions of the state that influence health policymaking and health system governance in addition to government. With health policy we mean all national or subnational policies that have an intentional bearing on population health and health care provision; health system governance refers to the steering of the health system with all its components. These definitions overlap, as they should, but as not all health policies relate to health system governance and not all governance decisions may be considered policies.

The chapter concentrates on the legislature and the judiciary, which are typically anchored in constitutional law (the United Kingdom is the example in which constitutional rules are in existence but are "unwritten"). Therefore, this chapter will examine the role of (1) parliaments in making legislation and scrutinising the actions of government, and (2) the legal system, forming the judiciary and its role in arbitrating conflicts between policy actors and in scrutinising the compatibility of decisions by government and parliament with existing law.

Understanding the role of the legislative and judiciary is important to contextualise the role of health ministries analysed in earlier chapters and their approach to making use of research evidence to inform decisions. The chapter takes the observation as a starting point that other bodies of 'the state' are often involved in the policy process and should therefore be considered relevant when we analyse the role of scientific evidence in health policymaking. Yet the constellation of these bodies varies between countries as they reflect differences in political systems, which translates into significant differences in how health policymaking and health system governance are influenced by them.

The chapter does not attempt to cover all bodies of the state relevant to health policy or all aspects of each country's political system. Instead, it aims to provide a broad overview by extracting relevant examples from the case studies of the GRIP-Health project and reflect on similarities and 
differences between them. There are few empirical studies of how evidence from research is incorporated in decision making processes within parliaments and courts (two of them included in this book), or if there are any, they are dispersed between different academic disciplines and not fully explored from the perspective of evidence-based policy-making. This chapter wants to highlight this gap by drawing attention to the relevance of legislators and courts in using evidence to exercise their mandate. It primarily does so by exploring the use of evidence in relation to their function of holding government to account, which has the benefit of allowing us to reflect on the checks and balances on governmental power and the limits of its decision-making relating to health policy.

\section{Institutions of the State and Their Role In Using Evidence for Health Policy-Making}

It is sometimes assumed that health policymaking largely takes place in central government, with ministries of health being the only state actors. Indeed, the WHO, highlighting the need for stewardship in health system governance, largely called on ministries of health to become responsible 'stewards' in driving health policy development and system reform (Travis et al. 2002). There are multiple critiques of this assumption, for example, with regard to countries in which responsibility for health are shared between different levels of government (Ettelt et al. 2010). This exists in many forms, for example in federalist countries in which responsibility for health policy is shared by different levels of government (Banting and Corbett 2001). But even among countries that are not federalist in the sense that they consist of a federation of states with separate state governments and parliaments, there is much variation with regard to the distribution of responsibility for health and the health system (Saltman et al. 2007). The United Kingdom with its four countries - England, Scotland, Wales and the Northern Ireland - is a case in point, as each country has its own health department and National Health Service, with only a few functions (e.g. emergency response) being centralised.

In addition, in many countries the decision-making power for health policymaking is also diffused among the institutions of the state, especially parliament and the judiciary. This particularly emphasises the role of national law, both in terms of making and in interpreting legislation, in health policy-making and system governance. The countries selected for this study cover different political regime types (ranging from democratic 
to non-democratic) and different constitutional structures (e.g. unitary vs. federal states; degree of executive control) (Ettelt et al. 2016). The comparison of political systems of the six countries selected for this study highlights three important differences:

- First, in some countries, the health policy and system governance function is highly centralised with the ministry of health being the main, and sometimes only player, with parliament and the judiciary being less influential. Ethiopia, Cambodia and Ghana broadly fall into this category for reasons that include both constitutional separation of power and practices of collaborative deliberation. In Ghana, for instance, in theory, parliament should approve the sectoral budgets for any financial year and coordinate its decision with the Ministry of Health responsible for the internal evaluation of the performance of the health system and its policies. Yet coordination does not happen in practice; while both processes tend to happen simultaneously, there is little overlap of the personnel involved in each and hence the coordination between both processes is limited. In Germany, in contrast, health system governance is almost entirely devolved to corporatist actors operating within a legal framework developed by the Federal Parliament, with the Federal Ministry of Health being only responsible for a relatively narrowly defined set of policy decisions and accountability functions (Ettelt et al. 2010).

- The second difference relates to the role of parliament in making health policy decisions and in scrutinising government actions in relation to policy development and health system governance. While parliament has some role in health policymaking in most countries, by way of debating, developing and eventually passing legislation, there are substantial differences in the extent to which parliament uses its powers to scrutinize government policy both ex ante and ex post, and the extent this scrutiny involves questioning the type of knowledge used to inform its decisions including scientific evidence.

- A third difference relates to the role of the judiciary in health policy and health system governance. Colombia and Germany stand out among the selected countries in this respect as in both countries the judiciary has a strong role in challenging the decisions of government and other health policy actors (e.g. the corporatist self-administration). The right to challenge these decisions in the courts is inscribed in constitutional law, which define both the balance of power within the state and the scope for action by citizens and others (e.g. provider organisations, 
insurers, corporatist actors) to defend their rights in case of violation. In other countries, in contrast, the judiciary is more restrained in intervening in government decisions either because of customary authority given to the government (in England) or because the judiciary is not sufficiently independent from those ruling in government (in Cambodia).

In the following two sections the role of the legislature and the judiciary and their potential for evidence use will be investigated in more detail, starting with the role of parliaments.

\section{Legislatures: The Role of Parliaments}

Given their constitutional role, parliaments should have a major influence on evidence use in health system governance and health policies. However, whether this happens in practice is an empirical question and this question has not yet been much researched.

In principle, there are (at least) two roles for parliament that can create opportunities for evidence use. The first role is to develop legislation and to set the legislative framework for health system governance. This includes initiating major health care reform (e.g. setting up the current system of health care financing in Colombia), but can also involve a broad spectrum of legislation that applies to any aspect of health care financing and delivery, health promotion, and preventative and public health measures (as discussed e.g. in the chapter on Ghana). Such decisions would warrant good information, hence there is a potential role for research evidence to influence these processes (constituting some form of 'instrumental' use).

The second role is for parliament to hold government to account for its decisions and actions. This can include both the use of scientific studies as a means to exercise accountability (e.g. evaluation of government policies or analyses of health system monitoring data) and the requirement of government and its constituent parts to demonstrate that decisions are well founded, which may include considerations of supporting evidence from research.

The analysis of the countries selected in this book suggests that there is great variation in the role of parliament in using, and enforcing, evidence use in health policymaking. Crucially, parliaments vary in their involvement in health policymaking, but also in the extent to which they hold government to account. In some countries, as outlined above, health policymaking and health system governance are mostly the domain of the 
executive with parliamentary involvement and oversight being limited or non-existent (Newman et al. 2013). In other countries, parliaments decide on a wide range of health policies and health system governance issues. As an example, Parliaments in England and Ghana both approve the budget allocation for health care. The Federal Parliament in Germany (composed of the Federal Assembly (Bundestag) and the Federal Council (Bundesrat)), in contrast, does not have authority over the budget, as this is held jointly by sickness funds as funds are collected through a social insurance system. Yet in Germany, the Federal Parliament plays a crucial role in setting, and monitoring, contribution rates to social health insurance thus influencing the ability of sickness funds to increase the budget significantly.

The analysis of the country case studies suggests that there is great variation as to the role of parliament in using, and enforcing, evidence use in health policymaking. Overall the verdict is not positive. In our study, examples of parliaments or parliamentarians engaging with research and opportunities for using evidence to come to better informed decisions were few and far between, particular with regard to informing legislative decisions. The analysis of minimum volumes policy in Germany (aimed at improving outcomes of complex interventions in hospitals) is a case in point. Parliament seemed not to have engaged with any evidence, despite the fact that the policy proposal was inspired by findings from health services research. Yet the scientific evidence base for minimum volumes became a major cause of disagreement at later stages of the policy process, including in the courts. In Germany, both chambers of Parliament are supported by an in-house scientific service, but its role is largely invisible to the public (it briefly surfaced in a recent scandal where a minister had used the service to co-write his $\mathrm{PhD}$ (Blechschmidt et al. 2011)). A recent study on the role of research in the UK Parliament, conducted by researchers of the Parliamentary Office of Science and Technology, concluded that almost all Members of Parliament and their staff participating in the survey ( 83 out of a total of 85 ) found research evidence useful for their work. However, most respondents applied a wide definition of what they meant by 'research' and 'evidence', including scientific research as well as other forms of research and knowledge (Kenny et al. 2017).

Countries also vary in whether health policy is mostly made through legislation, like in Germany and Colombia, or whether decisions relating to health policy and health system governance are mostly made through government decree and secondary legislation. Colombia's bicameral Parliament (the Congress) plays a substantial role in health system governance as most 
aspects of health policy are based on primary legislation (although there is also the possibility of a presidential decree). When the current system of health care financing was created through 'Law 100' in 1993 it was expected that much of the detailed principles that are required for its full implementation would be developed by subsequent legislatures. However, this has proven to be a slow process with the Congress having difficulties in forming sustainable majorities to make substantial decisions over a longer period of time as required for the implementation of Law 100.

Weyrauch et al. (2016) note that political parties can play a prominent role in channelling scientific evidence to inform legislation. However, in Colombia, to stay with the example, Parliament has a reputation for being fragmented and its members tend not to vote along party lines. Political parties are deemed weak and "lack[ing] the coherence and stability needed to effectively make policy" (Pachón and Johnson 2016: 73). This tendency to fragmentation in consequence allows the Government to exercise power over Parliament and orchestrate legislative action. Pachon and Johnson (2016) note that bills brought forward by the Government have a much higher chance to be turned into legislation than bills promoted by members of parliament, suggesting that the Government has substantial influence over the legislative process, for example by influencing the selection of chairs and rapporteurs on parliamentary committees.

In our case study on Colombia, Alvarez-Rosete and Hawkins (in this book) demonstrate that legislation is often justified by reference to scientific evidence and it is possible that committees engage with studies relating to relevant topics. However, it is difficult to see what incentives members of parliament might have to use evidence or scrutinise the Government's use of evidence. Dargent (2015) also noted that, in Colombia, Ministry of Health officials hold most technical expertise and have often play a pivotal role in informing the development of health legislation, again tipping the balance in favour of government.

One condition for parliaments to exercise their function to oversee governments is that the legislature has a degree of independence from the executive. Arguably, this is inherently difficult in parliamentary systems in which the executive is formed by majority holders elected into parliament. However, the question is whether parliament is sufficiently separate from government so that members of parliament see it as their collective responsibility to hold their government to account. If this is not the case, for example where both government and parliament are dominated by the same group of people (as in Cambodia), it is unlikely that parliament is in a position to review and challenge government actions. 
Parliaments can also be limited in their capacity to scrutinise proposals from the executive, which produces the vast amount of legislative initiatives. In Ghana, the Select Committee on Health can initiate inquiries on health policy matters to hold the Government to account, but its efforts are constrained by its limited budgetary and professional capacity.

Lindberg (2010) notes that Parliamentary scrutiny of government policy in Ghana was high in the years 1997-2000 (the second presidential term of Jerry John Rawlings in the Fourth Republic), with subsequent parliaments being less active in challenging government action. The problem Lindberg diagnoses is that members of parliament are themselves not held to account by their constituents for their role in scrutinising government, but are rewarded, and kept in post, for their ability to secure resources for local projects and investments. Access to such resources is controlled by the Government which therefore can reward (or penalise) members of parliament for their support (or the lack of it) for government decisions. Mechanisms such as questions to the Government from the floor are possible, but they are more likely to be used to inquire about progress in the implementation of local projects than about policies relevant to the populace as a whole (Lindberg 2010). With the accountability function being ineffective, the ability of parliament - while democratically elected and thriving in this respect - to scrutinise government is weak. This weakness is compounded by a lack of resources and capacity of parliamentary services.

The importance of accountability mechanisms for evidence use is also highlighted by the role of the Parliament (composed of the House of Commons and the House of Lords) in the UK. The UK Parliament passes primary legislation relating to health, which provides the framework for the National Health Service (NHS), public health and other health-related policies. It also scrutinises health policy that the Government develops and implements via secondary legislation through its Department of Health. A number of mechanisms are available for this purpose, including parliamentary debates, and questions put to ministers, the department and posed directly to the Prime Minister. Evidence from research may play a part in these mechanisms (Kenny et al. 2017), yet its use is highly variable, topic dependent and often superseded by debates about the worthiness of policy goals in the first place. The debate about the controversial 2012 health care reform is a case in point, in which Members of Parliament challenged the intention of the Government to privatise the NHS much more forcefully than they demanded the existence of any studies in support of the 
proposal for large-scale restructuring and the strengthening of provider competition (Timmins 2012). The Government was criticised for not using evidence, but this critique came from actors outside the legislature, such as policy think tanks (IoG 2012).

Both the House of Commons and the House of Lords are supported in their work by research and library services, however, the extent to which these information services are used and are seen as relevant by members is highly variable. In contrast, scientific evidence is often central in the work of the Health Select Committee. In the 2015-17 Parliamentary term, the Committee conducted 24 inquiries on topics as wide ranging as the state of the NHS finances, the Government's actions on suicide prevention, the effects of Brexit on health and social care services, and the state of public health after the restructuring of the sector in 2013. The Committee invites public sector and civil society organisations to make submissions for a topic, which are often bolstered by substantial references to studies. It also invites a broad range of experts, including researchers, to give evidence before the committee. After deliberating the evidence from all sources (scientific or not), the committee publishes its verdict in a report available from its website (e.g. HoC 2016). However, the extent to which UK Select Committees are able to hold the Government to account is debated. King and Crewe (2013: 355), in their book "The blunders of our Governments", argue that such committees "seldom seek to delve deeply into the origins of policies as distinct from their merits and generally fight shy of addressing issues that already are, or might become, issues of partisan controversy".

\section{The Judiciary: The Role of Courts}

The judiciary - often referred to as the third power of the state - applies and interprets the law of a country in the name of the state. Countries vary in whether the judiciary can have a role in developing legislation, either through commenting, or even approving, proposed bills or through setting precedence that informs future decisions of courts.

This function is represented, for example, by the Constitutional Court in Colombia, which has authority, as per the Colombian constitution, to review legislation passed by the Congress if the bill affects constitutional rights (Hernández Álvarez 2013). The Constitutional Court can also decide to step in if it finds that legislative and executive bodies have failed to act. This has created a dynamic in which political actors tend to defer to the Court for resolution on contested issues that they are unable to resolve by other means. 
The judiciary can also have a role in holding the government and parliament to account, for example through the mechanisms of constitutional complaint or judicial review. In Germany, the Federal Government and Parliament tend to consult senior judges at the German Constitutional Court on policies that affect constitutional rights to avoid a retrospective "complaint of unconstitutionality" (Verfassungsklage) that can result in legislation being revoked and returned to legislators (Landfried 1994). There is no suggestion that courts are particularly interested or indeed equipped to advise other state bodies about matters of scientific evidence, as advice will be focused on aspects of legality and couched in legal terms only. However, depending on the issue in question it is possible that studies play a role in legal argumentation in case of review (as demonstrated in the chapter on minimum volumes in this book).

However, it is not a given that courts are in a position to challenge governments as this (as with parliament) requires a good degree of independence between the executive and the judiciary. Courts can also arbitrate in conflicts between individuals and organisations, often using a broad spectrum of law that has a bearing on health and health policy (e.g. medical law; social law; criminal law, administrative law). In some countries, courts play a prominent role in arbitrating access to care decisions, especially those that provide a constitutional right to health or health care (e.g. Colombia, Germany). These decisions typically cut across litigation on behalf of individuals (i.e. patients, members of sickness funds) and the politico-administrative system mandated with making decisions about collective health service coverage (for example through bodies such as the National Institute For Health and Care Excellence (NICE) in England or the Institute for Health Technology Assessment (IETS) in Colombia).

Such litigation is widespread in Colombia, where a constitutional right to health provides the legal basis for patients to challenge decisions by insurers if these deny funding treatments. Between 1999 and 2014 over 1.3 million right-to-health cases were brought to the Constitutional Court (Defensoría del Pueblo 2015). Such court cases draw on the legal instrument of 'tutelas' which are "informal and expedite injunctions that allow citizens to seek judicial protection when their basic rights are threatened by the state or by a third party" (Lamprea 2014: 133). The court therefore has the power to reverse a decision made by insurers, both public and private, as well as decisions made by IETS, even if these decisions have been based on rigorous health technology assessment. This is problematic, as the right to health is interpreted in a way that allows individuals to have 
access to (government-funded) treatment even if this treatment is proven to be ineffective or excessively costly.

Pharmaceutical companies have latched on this opportunity and have made a business model of providing legal support to patients to gain additional funding. However, while the behaviour of the court has been decried as inappropriately interventionist, it has also been argued that this is the only route that patients can take to challenge the decisions of insurers. The argument is that the Ministry of Health has been unable to effectively regulate and police the behaviour of insurers and the price setting of pharmaceutical companies that both could help to ease pressure on courts. Lamprea (2014: 158) therefore suggests that the Constitutional Court in Colombia acts like the proverbial "canary in the coal mine that signals deeper institutional dysfunctions within Colombia's health sector".

Courts in Germany have a prominent role in access to treatment decisions, but in contrast to Colombia most cases are dealt with by Social Courts (i.e. a system of courts concerned with social security matters) rather than the Federal Constitutional Court. In 2005, the Constitutional Court laid down rules for applying the constitutional 'right to life' included in the German Basic Law (which expands to a right to health care). This decision provides the basis for the decisions of all courts to which these rules apply, forcing sickness funds to reimburse treatment, including in cases in which evidence of effectiveness was absent or highly questionable (Ettelt in press). However, compared with Colombia, the caseload in Germany is relatively modest, with less than 400 cases between 2005 and the end of 2015 (RUB 2016).

In contrast, courts play a much more limited role in treatment decisions in England, where no constitutional right to health exists. Since the inception of NICE, there have been less than a handful of cases in which NHS patients sought legal redress against decisions by NICE to withhold (or, more precisely, not mandate local NHS organisations to provide) treatment in the NHS. Littlejohns et al. (2012) noted that there is only a narrowly defined set of reasons that patients can employ to take NICE, or any Government agency, to court. These reasons are that NICE has exceeded its mandate (defined by Parliament and the Secretary of State for Health), that the institute acted unfairly or that the decision cannot be 'reasonably' justified, all of which can be refuted by reference to mandate and procedure, which can include reference to appropriate use to scientific evidence (also Syrett 2010). 
However, more recently, there were a number of cases of patients who took NHS England (the central governance body overseeing the NHS) to court for rejecting applications for treatment funding. In May 2016, the High Court ordered NHS England to provide a teenager with narcolepsy with the requested drug at least for three months, in spite of NHS England not considering the drug as sufficiently cost-effective (HSJ 2016). The court ruled that the case met the criteria of "exceptionality" and judged that the reasoning of NHS England was "unsupportable". Yet such legal challenges to treatment decisions of NHS governing bodies that are effectively government agencies are considered unusual and undesirable, as it is argued that courts should not become involved in decisions about resource allocation. Such decisions should be made by government and related administrative bodies (Ford and Tracy 2016).

In interviews, conducted in Cambodia, Ghana and Ethiopia the judiciary was not mentioned as an institutional actor that impacts on health policy or health system governance decisions. This may be a reflection of our interview strategy but it also resonates with our observation of the unstable or emerging role of the judiciary in these countries and/or a lack of judicial independence that does not allow courts to challenge the government. Cambodia, for example, only begun (re-)building its judicial system after democratisation in 1993 following several decades with no legal system in place. However, the judiciary is institutionally weak and dominated by the interests of the ruling elite which also dominate the executive and legislature (Dressel 2014; McCarthy and Un 2015). There is therefore no mechanism through which the judiciary could hold the government to account (with the trial against former Khmer Rouge leaders being a potential exception) and courts are unlikely to be involved in health policy decisions.

\section{The Institutions of the State Matter for the Study of Evidence Use in Health Policy and Health System Governance}

This chapter has discussed a number of examples from our programme of work that illustrate how the design and functioning of state institutions can shape the accountability mechanism between the government, parliament and the judiciary and the different places in which decision-making in relation to health policy and health system making can happen at the national level. While ministries of health are the pivotal (if not only) actors in health policymaking, their role is highly dependent on the institutional configuration of the state. 
Our country case studies showed a variety of such constellations, particularly focusing on parliament (legislature) and courts (judiciary), their role in scrutinising government policy and their involvement in decision making relating to health policy. While there are few studies specifically examining the role of evidence use in decisions in parliaments or the judiciary this chapter wants to shine a spotlight on the fact that these institutions often have a role in health policymaking and health system governance which should not be overlooked.

The chapter hints at a number of tensions between decision-making structures and demands for better use of research evidence in policy-making.

Parliament provides a key mechanism for holding government to account, however, this is not a given and in many situations this is not sufficiently exercised. There are many reasons why parliaments can find it difficult to hold governments to account, although these are likely to vary greatly. It also can be argued that attention of parliament for government activities, in health or elsewhere, is likely to be sporadic and incomplete, and depended on the interests, qualification and attention span of their members. However, in countries in which the parliament (often through committees) uses evidence and demands evidence use from the government, this can provide a powerful stimulus for better evidence use throughout the sector.

There are only a few examples of courts being involved in health policy decisions within the scope of this book. Examples of court involvement in access to treatment decisions in Germany and Colombia show that the relationship can be complicated with courts likely to give preference to constitutional principles that emphasise individual rights over concerns about effectiveness or affordability. However, different judicial practices in different countries have brought about a variety of approaches that may or may not include an assessment of evidence from studies. Courts can also have a place in reviewing Government policies through mechanisms such as judicial review or 'constitutional challenge', although the effect of evidence use is unclear.

\section{REFERENCES}

Banting, K.G., and S.M. Corbett. 2001. Health policy and federalism: A comparative perspective on multi-level governance. Kingston: Institute of Intergovernmental Relations, Queen's University.

Blechschmidt, P., T. Schultz, and R. Preu $\beta$. 2011. Guttenberg helped himself to six Bundestag reports [Guttenberg bediente sich bei sechs BundestagsExpertisen], Süddeutsche Zeitung, February 25.

Dargent, E. 2015. Technocracy and democracy in Latin America: The experts running government. Cambridge: Cambridge University Press. 
Defensoría del Pueblo. 2015. La Tutela y los Derechos a la Salud y a la Seguridad Social [The tutela and the right to health and the social security]. Bogota: Defensoría del Pueblo de Colombia.

Dressel, B. 2014. Governance, courts and politics in Asia. Journal of Contemporary Asia 44 (2): 259-278.

Ettelt, S. in press. Access to treatment and the constitutional right to health in Germany: A triumph of hope over evidence? Health Economics, Policy, and Law.

Ettelt, S., N. Mays, K. Chevreul, A. Nikolentzos, S. Thomson, and E. Nolte. 2010. Involvement of ministries of health in health service coverage decisions: Is England an aberrant case? Social Policy and Administration 44 (3): 225-243.

Ettelt, S., B. Hawkins, and A. Alvarez-Rosete. 2016. Analysing evidence use in national health policy-making - An institutional approach. http://blogs.lshtm. ac.uk/griphealth/files/2016/09/Analysing-evidence-use-in-national-healthpolicy-making-an-institutional-approach.pdf. Accessed 15 Nov 2017.

Ford, G., and J. Tracy. 2016. Judicial review update: NHS England ordered to fund treatment. Hempsons (Lawyers), London, July 22. http://www. hempsons.co.uk/news/judicial-review-update-nhs-england-ordered-fundtreatment. Accessed 26 Oct 2016.

Hernández Álvarez, M. 2013. Ley Estatutaria debe superar el debate tecnócrata. Un periódico 166 (6).

HoC. 2016. Public health post-2013. Second report of session 2016-17. London: House of Commons Health Committee.

HSJ. 2016. Third time lucky for NHS England? HSJ, 3 August 2016.

IoG. 2012. Learning the lessons from 'never again'? London: Institute for Government.

Kenny, C., D.C. Rose, A. Hobbs, C. Tyler, and J. Blackstock. 2017. The role of research in the UK parliament. Volume one. London: Houses of Parliament.

King, A., and I. Crewe. 2013. The blunders of our governments. London: Oneworld.

Lamprea, E. 2014. Colombia's right-to-health litigation in the context of health care reform. In The right to health at the public/private divide. A global comparative study, ed. C.M. Flood and A. Gross, 131-158. Cambridge: Cambridge University Press.

Landfried, C. 1994. The judicialization of politics in Germany. International Political Science Review 15 (2): 113-124.

Lindberg, S.I. 2010. What accountability pressure do MPs in Africa face and how do they respond? Evidence from Ghana. Journal of Modern African Studies 48 (1): 117-142.

Littlejohns, P., T. Sharma, and K. Jeong. 2012. Social values and health priority setting in England: "Values" based decision making. Journal of Health Organization and Management 26 (3): 363-371.

McCarthy, S., and K. Un. 2015. The evolution of rule of law in Cambodia. Democratization, Published online December 28. http://www.tandfonline. com/doi/full/10.1080/13510347.2015.1103736 
Newman, K., A. Capillo, A. Famurewa, C. Nath, and W. Siyanbola. 2013. What is the evidence on evidence-informed policy making? In Lessons from the International Conference on Evidence-Informed Policy Making. Oxford: International Network for the Availability of Scientific Publications.

Pachón, M., and B.B. Johnson. 2016. When's the party (or coalition)? Agendasetting in a highly fragmented, decentralized legislature. Journal of Politics in Latin America 8 (2): 71-100.

RUB. 2016. Nikolaus project. Overview of decisions [Nikolaus-Projekt. Übersicht der Entscheidungen]. Ruhr-Universität Bochum. http://nikolaus-beschluss. de/decisions. Accessed 12 Nov 2016.

Saltman, R.B., V. Bankauskaite, and K. Vrangbæk, eds. 2007. Decentralization in health care. Strategies and outcome. Maidenhead: Open University Press.

Scott, Z., and C. Mcloughlin. 2014. Political systems: Topic guide. Birmingham: GSDRC, University of Birmingham.

Syrett, K. 2010. Health technology appraisal and the courts: Accountability for reasonableness and the judicial model of procedural justice. Health Economics, Policy and Law 6 (4): 469-488.

Timmins, N. 2012. Never again? The story of the health and social care act 2012. London: The King's Fund and Institute for Government.

Travis, P., D. Egger, P. Davies, and A. Mechbal. 2002. Towards better stewardship: Concepts and critical issues. Geneva: World Health Organization.

Weyrauch, V., L. Echt, and S. Suliman. 2016. Knowledge into policy: Going beyond 'context matters'. Oxford: INASP.

Open Access This chapter is licensed under the terms of the Creative Commons Attribution 4.0 International License (http://creativecommons.org/licenses/ by $/ 4.0 /)$, which permits use, sharing, adaptation, distribution and reproduction in any medium or format, as long as you give appropriate credit to the original author(s) and the source, provide a link to the Creative Commons license and indicate if changes were made.

The images or other third party material in this chapter are included in the chapter's Creative Commons license, unless indicated otherwise in a credit line to the material. If material is not included in the chapter's Creative Commons license and your intended use is not permitted by statutory regulation or exceeds the permitted use, you will need to obtain permission directly from the copyright holder.

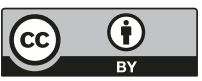

